\title{
Significance of Traditional and Advanced Morphometry to Fishery Science
}

\author{
Subodh Kumar Tripathy ${ }^{1 *} \oplus$ \\ ${ }^{I}$ Department of Zoology, Anchal College, Padampur, Dist: Bargarh, Odisha, India.
}

Received 24 May 2020; Revised 03 August 2020; Accepted 17 August 2020; Published 01 September 2020

\begin{abstract}
Morphometric characters of fishes are measurable or metric characters. Morphometrics is a more or less interwoven set of large statistical procedures to analyze variability in the size and shape of organisms. Morphometrics and phylogenetics of a species are combined to utilize existing phylogeny, which addresses hypotheses of shape change through evolutionary time. Morphometric differences among stocks of a species are recognized as important for evaluating population structure and forming a basis for identifying stocks. Advancements in morphometrics have used powerful tools for testing and displaying differences in shape, isolating shape from size variation, and identifying stocks of species with unique morphological characteristics, enabling better management of the species. Traditional or standard morphometry has been improvised from time to time with advanced methods by technological advancements like geometric morphometrics, image analysis, principal component analysis, truss network analysis, and multivariate analysis, as well as many more, to update knowledge and get more accurate information. These advanced methods have strengthened earlier technologies to improve and upgrade fishery research throughout the globe.
\end{abstract}

Keywords: Morphometry; Truss Network; Image Analysis; Multivariate Analysis; Principal Component Analysis.

\section{Introduction}

An organism expresses its phenotypic characteristics as a result of its genetic constituents as well as environmental influences. Morphometrics was defined as a more or less interwoven set of large statistical procedures to analyze variability in the size and shape of organs and organisms. Nayman [1] described morphological systematics as the measurement of morphometric characters and meristic accounts, which was considered the most authentic and easiest method to identify a specimen. According to Talwar and Jhingran [2], morphometry is the external measurement of body parts of an organism, whereas meristic characters are countable characters. Most of those characters with significance to economic traits in fish and fisheries are measurable (metric) or quantitative, showing individual variations within a population and their magnitudes depend on a large number of factors, such as the number of genes and various environmental parameters $[3,4]$. In comparison to any other vertebrate, fishes show greater differences in morphological traits in between the populations and within species [5,6]. Random fluctuations in these traits in an organism are desirable to destabilize development governed by endogenous factors or exogenous environmental perturbations [7]. Avsar [8] reported that animals with the same morphometric characteristics were believed to belong to the same species. Kovác \& Copp [9] state that morphometric study is a fundamental tool to understand the growth and development of

* Corresponding author: sbskt04@rediffmail.com; sbskt04@gmail.com

$>$ This is an open access article under the CC-BY license (https://creativecommons.org/licenses/by/4.0/).

(C) Authors retain all copyrights. 
organisms, their systematic variations, and the structure of their population characteristics. Interactive effect of environment, selection and heredity on body shape and size of a species can be studied by this tool [10]. Morphometric differences among stocks of a species are recognized as an important method to evaluate population structure and identify stocks $[11,12]$. Turan [12] informed us that such analyses were commonly used to identify stocks of fish and to establish evolutionary linkages between ancient and modern fish faunas. Different fish populations exhibit differences in their morphometric characters [13]. Hence, there exist variations among different populations of a species in their body shape and size due to external environmental conditions and various factors. Therefore, study of morphometric character is an important tool used by fishery scientists globally for identification of stocks and various other purposes.

Murta [14] and Pinheiro et al. [15], morphometric variations between stocks provide a basis for stock structure, which could be applied to study short-term, environmentally induced variation geared towards successful fishery management. Such studies in fishes have mostly used classical dimensions [16-19]. Such analyses were used to identify different stocks of fish species, populations, and races [20]. Smith \& Jamieson [21] and Randall \& Pyle [22] informed that, morphometric differences among stocks of a species are recognized as important tool to evaluate population structure and form basis to identify stocks. According to Hossain et al. [23], fishes quickly adapt themselves by changing necessary morphometrics as they are very sensitive to environmental changes. Morphometric traits prove to be the most frequently employed and cost-effective method for identification of a species [24]. The field of fishery science has employed many tools such as genetics and morphometrics to differentiate fish populations [25]. Information on the biology and population structure of any species is a pre-requisite to developing proper strategies for their conservation and management [26]. As stated by Chaklader et al. [27], by detecting changes in the shape, morphometric characters could be used to quantify traits of evolutionary significance. As per Chakravorty et al. [28], morphometry is an essential tool to provide a concept of the size and shape of the specimens, thus making identification of species taxonomically significant and also serving as an essential tool to determine variations among them. Begum et al. [29], Mekkawy \& Mohammad [30], and Satyanarayana \& Ratnakumari [31], morphometric variations or biometric analysis are employed to identify and find out variations in different fish stocks at species level. Batubara et al. [32] summarized that morphometric characters are part of morphological characters to analyze quantitative measurements like size and shape. Traditional or standard morphometry has been improvised from time to time with advanced technologies like image analysis, principal component analysis, truss network analysis, and multivariate analysis, as well as many more, to update knowledge and get more accurate information. Keeping the availability of an array of earlier references on the application of morphometry in fishes in view, this review was done stating its significance to fishery research throughout the globe. The aim of this article is to emphasize the significance of morphometry in genetics, evolution, systematics, and taxonomy of fishes as well as applied aspects like stock management and identification.

\section{Morphometry}

Morphometric analysis is an age old traditional practice in fisheries research since 1980's, hence there exists a vast array of literature to enrich pertinent knowledge in this regard. Balon [33] suggested all morphological measurements need to be converted to percentage of standard length to analyze body parts accurately calculating standard error of mean. Various fish populations were recognized by using such measurements [34-36]. The analysis helps to know the origin of stock, separation of stocks or identification of commercially important species of fishes [37-39]. Carpenter et al. [40] reported that, such study plays important role to estimate relationship between various parts of body. Two types of morphological characters like morphometrics and meristics were frequently employed to represent the stocks of a variety of exploited fish species [12, 14, 41, 42]. It is assumed that, characters are independent of each other and some of the controversy about the use of morphometric data in phylogenetics relates to no common underlying causes [4345] however, shape variables extracted from a morphological structure jointly make up the shape as a whole and normally cannot be assumed to be independent of each other [46]. According to Naeem \& Salam [47], morphometric and meristic studies are dynamic tools to measure discreteness of same species. According to Sarder \& Simonsen [48], taxonomists carefully count meristic characters and measure multiple morphometric variables of body shape to examine external body features; however Eklov \& Svanback [49] stated that, freshwater fishes display a range of morphological adaptations. According to them, though there is a risk of misidentification during visual assessment, it is employed to discriminate fishes [48]. As reported by King [50] the morphometric relationships among different body parts of the fish could be used to determine possible differences between separated populations of the same species. Morphometric measurements were widely used to identify differences between fish populations [51-53].

On the utilities of morphometric characters in fishes it was reported by Cadrin \& Silva [54], Chaklader et al. [55] and Siddik et al. [56] that, it was one of the simplest, most cost effective and most commonly used tools to identify and characterize fish stocks to determine the structure of fish assemblages [51] and distinguish fish populations [51, 57]. The degree of homoplasy in morphometric data was expected to be negatively associated with the strength of phylogenetic signal [46] and there occurred across a wide variety of physiological states and environmental conditions randomly approximating to event(s) shaping a normal distribution pattern as a result of genetic divergence and phenotypic plasticity. Poulet et al., Turan et al. and Akbarzadeh et al. [58-60] realized the importance of both genetic 
and environmental factors on morphometry and morphological characters of fishes. Poulet et al. [58] recommended that these two factors and their interaction influence morphological characteristics where the environmental factors might be availability of food, distance of migration, temperature and salinity with potentiality to determine morphometric discrimination of fishes [59]. Akbarzadeh et al. [60] reported significance of these factors on morphological differentiation in fish. Morphometrics and phylogenetics could be combined to utilize existing phylogeny addressing hypotheses of shape change through evolutionary time [61]. On the utility of morphometry, Mojekwu \& Annumudu [26] reported that, it allows more rigorous comparisons of metric characters adding quantitative elements which enable rigorous description of complex shapes permitting numerical comparison between different body forms. Usually, conversion of morphometric measurements in percentage of standard length, head length and caudal peduncle length or parts of thousands of standard length in fishes are described to establish phenotype of a species/variety depicting expected inheritance. Morphometric characters respond to changes in environmental factors which differ from species to species [62].

\section{Advancements in Technology}

During early investigation of morphology, the measurements were limited to selected body structures like locations of fins with poor or no ability to quantify body shape [63].Traditional morphometrics mostly relied upon measurements of shape indicators like lengths, areas, angles and their ratios [64, 65]. Combination of multivariate and geometric methods as per Silva [41] increased the chance of detecting small differences in morphometry as anticipated at an intraspecific level since geometric methods took into account of geometry of configurations providing additional information on shape differences which is not available from multivariate methods [66]. It focused on aspects of selected shape only; as a consequence the original shape could not be reconstructed from the measured indicators. Different Mathematical models with few homologous points converted outline geometry into quantitative variables for multivariate framework. RWA was essentially a morphometric principal component analysis of relative landmark positions using variance/covariance matrix producing a series of orthogonal axes ranked by the amount of shape variation explained and all shape axes were retained for analyses [67]. Those measurements were concentrated along the body axis with sampling from depth and breadth only, where most of the measurements were from the head.

\subsection{Land Mark Based Morphometry}

Modern morphometry as per Rohlf [68] and Bonhomme et al. [69] considered entire shape through approaches like configuration of landmarks and outline analysis. The power of landmark based morphometry is to separate fish based on varying body form supporting the enhancement of this technique for field based diagnosis [70]. Obtaining traditional morphometric measurements is laborious and slow process as taxonomists manually generate data from numerous specimens [71]. But later on, various methods have been developed for estimating phylogenetic signal from morphometric data [46]. Mojekwu \& Annumudu [26], the techniques of morphometry measurement emerged with various advancements to analyze fish population which included truss network measurement, image analysis, univariate, bivariate and multivariate analysis as well as principal component analysis (PCA). These methods quantified variations in shape of anatomical objects using the Cartesian coordinates of anatomical landmarks, keeping the effects of nonshape variations constant mathematically. Advancements in morphometrics used powerful tools for testing and displaying differences in shape, isolate shape from size variation and identifying stocks of species with unique morphological characteristics. This enabled a better management of species subunits and ensured better management of the fishery resources. Caillon et al. [72] modern morphometrics encompasses an array of mathematical approaches that turn shapes into quantitative variables.

\subsection{Geometric Morphometrics}

Bookstein [73], reported about Geometric Morphometrics as a statistical method of analyzing shape variation and its co variation with other variables. According to Adams et al. [61], Cavalcanti et al. [74], Parson et al. [75] and Toscano et al. [76], this was considered to be the most rigorous, cost effective and user friendly technique. It captures information on the shape of an organism from digital images with more powerful statistical analyses for species differentiation. Toscano et al. [76] revealed morphometric variations between the hybrids of roach (Rutilus rutilus L.) and bream (Abramis brama L.) and their parental species inhabiting an Irish lake using Geometric Morphometrics. Echem [77] reported, geometric morphometric analysis to generate shape variation of Sardinella lemuru and revealed that, shape variation could be accounted to their genetics and evolutionary adaption where phenotypic plasticity allowed to respond and adapt to environmental change by modifying their morphology and behaviour leading to changes in morphology, reproduction or survival that alleviate the effects of such environmental change.

\subsection{Truss Network Analysis}

According to Strauss \& Bookstein [78], the conventional morphometric measurements are redundant and most are along the longitudinal axis, having no geometric properties, whereas the truss network provides measurements that cover the entire body representing the shape of the animal. The truss is a system of vertical, horizontal and oblique distances 
measured between preselected anatomical landmarks which are points, chosen to divide the body into functional units identified on the basis of local morphological features [79]. This method has advantages over conventional morphometric character sets that usually comprise length, depth, and width measurements. Many authors concord that, truss dimensions measurements including components of body depth and length along the longitudinal axis having theoretical advantages over classical morphometric characters to discriminate among groups $[17,18,78,80,81]$. This system [78] has been increasingly used for stock identification from time to time [3, 12, 63, 82-87] covering entire fish in a uniform network theoretically increasing the likelihood of extracting morphometric differences between stocks. Preliminary investigations on populations of anchovies in Turkish terrestrial waters [88] used truss network system for morphometric characters to reveal high degree of dissimilarity and indicated that the anchovies in each sea represent different aggregations. Truss networks of distances between landmarks coordinates have greater discriminating power providing more comprehensive coverage of form [89, 90]. Dwivedi \& Dubey [91], it is a more useful and effective strategy to describe shape with better data collection and diversified analytical tools in comparison to traditional morphometric method. According to Mojekwu \& Anumudu [26], some arbitrarily selected points on a fish body are known as landmarks which help to analyze individual fish shape. A landmark is a point of correspondence on an object that matches between and within populations. Park et al. [92] analyzed classical and truss dimensions to discriminate different species of dark banded rockfish, black rockfish, striped shiner and the slender shiner. Suryaningsih et al. [93] reported application of truss morphometrics technique in silver barb (Barbonymus gonionotus) to distinguish male and female stating that, male fish had a more elongated body size than female.

\subsection{Principal Components Analysis}

PCA is a multivariate statistical technique that uses orthogonal transformation to convert a set of correlated variables into a set of orthogonal uncorrelated axes called principal components [94, 95]. According to Silva [41], principal components analysis on size corrected truss variables and cluster analysis of mean fish shape using landmark data indicated that the shape of sardine off southern Iberia and Morocco is distinct from the shape of sardine in the rest of the area. Multivariate techniques like principal components (PCA) and discriminate analyses quantified morphometric variables receiving increased attention in stock identification [96-100].

\subsection{Multivariate Analysis}

As per Cadrin [10], morphometric methods were developed and applied to discriminate stocks like univariate comparisons, bivariate analyses of relative growth pattern and a series of multivariate methods. It enabled condensation of data on a multivariate phenomenon into its main, representative features by projection of data into a two dimensional presentation. Hard et al. [101] analyzed in Coho Salmon by multivariate analysis of shape variation through procrustes coordinates, visualized by thin plate spines indicating adults reared in captivity and differentiated from the wild fish showing sharply reduced sexual dimorphism as well as smaller heads and less hooked snouts, increased trunk depth, larger caudal peduncles, shorter dorsal fins, larger hind bodies and a reduction in body streamlining. Martinez et al. [102] analyzed morpho-structural model of Dormitator latifrons through multivariant techniques evaluating effects of sex and production system and reported that, they exhibited sexual dimorphism with insignificant differences in morphometric measurements. Vatandoust et al. [103] compared morphometric characteristics of two groups of Caspiomyzon wagneri noting some ranges of overlapping in multivariate analysis.

\subsection{Image Processing Analysis}

Cadrin \& Friedland [11] assessed the enhanced use of image processing techniques but reported that it was not applied frequently to morphometric analyses in fisheries research. But later on, the image analysis systems played a major role to develop morphometric techniques boosting the utility of research. The characteristics were more applicable to study short term, environmentally induced disparities, stock identification [89, 90], species differences, practical morphology and improved fisheries management [88]. Costa et al. [104], this form of morphometric analysis offered more efficient and powerful techniques like image analysis to detect differences among groups differentiating between species of similar shape.

\section{Application in Global Fisheries}

Shubinkova [105] analyzed morphometric characteristics to report variability in silver carps whereas Ihssen et al. [106] reported utility of morphometry in fisheries to solve problem of stock differentiation and life cycle. According to Ihssen et al. [106], morphometric analysis was one of many tools available for identification of fish stocks which had been applied to many stock differentiation and life history problems [3, 63, 107-111]. It was reported in rainbow trout by Leary et al. [112] from morphometric analysis that there were some asymmetry in morphotype expression and development with low variability. Spanakis et al. [113], found significant genetic and morphometric differences between the Aegean and Ionian Sea populations of Azov Anchovis. Reist et al. [114] detected hybrids among coregonid fishes based on morphological variations. Beeman et al. [110] proposed the utility of morphometric indices in salmonids as a non-lethal measure of smoltification assessment replacing other contemporary methods like physiological, biochemical 
and endocrinal requiring killing of animals. Measuring the morphometric characters and calculating the canonical variate is a relatively simple procedure and can be performed with little harm to the fish [110]. As stated by Carvalho \& Hauser [115], stock identification is an integral component of modern fisheries stock assessment studies for efficient fisheries management. Balon [33] stated that, a body depth in carps reflected condition, sex and possible lotic or lentic environment. Large body depth in common carp was an indicator of domestication reflecting the probable habitat status and conscious selection [33]. Baranyi et al. [116] conventional morphometric analysis used external measurements to reveal considerable morphological variations within samples involving body depth and fin size but did not allow adaptive eco-morphological interpretation with insignificant correlation limited by the narrow range of heterozygosity estimates. Rosenfield [117] realized the importance of meristic characterization augmented with morphological and color evidence to detect natural hybridization between pink salmon (Onchorhyncus gorbuscha) and Chinook salmon (O. tshawytscha). Cavalcanti et al. [74] studied morphometric variations among six species of serranid fishes and observed non-uniform changes in body shape.

Bronte et al. [4] correlated the genetic basis with whole body morphology of Baikal omul (Coregonius autumnalis, Georgii) with some meristic and classical morphometric measures for stock differentiation whereas Hockaady et al. [118] gave various mathematical models and methods of analyzing morphometry. Katoh \& Tokimura [119] compared measurements among different catfishes. Zafar et al. [120] reported in Mahseer (Tor putitora) that, all the meristic characters remained constant whereas morphometric characters gradually increased with increasing body length showing isometric growth pattern. Parsons et al. [75] revealed high morphometric variations in two cichlid fish species. Morphometric data of Sardines through truss variables and landmark were reported by Silva [41] from north eastern Atlantic and western Mediterranean by multivariate and geometric methods. Park et al. [16] investigated eye traits as measurements of head clarifying width between two eyes/distances between head length and premaxilla in catfish. Chakrabarty \& Ng [121] identified Mystus cavasius in Myanmar employing morphometric analysis. According to Analaura et al. [122], morphometric or biometric studies were used to estimate the percentage of fish harvested from length-weight data, determining the effects of environmental improvement to regulate fisheries.

Katselis et al. [123] studied morphometric variation among four grey mullet species of Mediterranean revealing high classification of species into their respective groups. Sakai et al. [124] studied morphological variation among three crucian carps from Ob River system Kazakhstan, revealing high morphometric variation among species based on landmark based morphometry. Hossain et al. [23] examined morphometrics along with truss network measurements and meristic counts of Labeo calbasu based on landmark analysis to evaluate their population status reporting some significant differences in four morphometric measurements, revealing high isolation of stocks. Engdaw [125] studied morphometric parameters of Labeo barbus intermedius in Ethopia finding significant linear relation between total length and standard length and between total length and total weight whereas Makmur et al. [126] estimated morphometric parameters of Hampala macrolepidota from Indonesia observing all measurements with significant positive correlation. According to Solomon et al. [127], farming of a particular fish species for several years could dilute initial gene pool to drive genetic variations manifested in morphological differences between cultured and wild Clarias gariepinus (Burchell). Jacquemin \& Pyron [128] studied morphological variation in Cyprinidae from lentic and lotic systems to gain insight into long term patterns in morphology. Siddik et al. [129] studied morphometric characters of Sillaginopsis paniijus to delineate stock structure and results showed different stocks in various rivers of Bangladesh.

Morphometric measurements were widely used to identify differences between populations of fishes [51-53, 130]. References for morphometry studies in fishes [3, 4, 33, 63, 105-112, 116-118] largely stressed upon importance of morphometric analysis as significant tool for stock identification in fishes. Turan [12], Corti et al. [82], Haddon and Willis [131], Turan [132], Pakkasmaa \& Piironen [133] and Turan et al. [134] reported well documented morphometric studies providing evidence for stock discrimination in fishes. Martinez et al. [102] reported regarding requirement of morphological and meristic characterization of chame (Dormitator latifrons) whose characterization was in an advanced stage as compared to other native species $[135,136]$, as all of which were reported to be interesting to conservationists. Olopade et al. [137] conducted research to study the morphological characteristics of Coptodon guineensis using morphometric measurements and meristic counts and showed that almost all the values of the external morphometric parameters were higher in the river population than those of from creek and revealed that freshwater population could be phenotypically separable from the brackish water population.

\subsection{Application of Morphometry in Indian Fisheries}

Various authors from India reported from time to time stating the utility of morphometric analysis in fish and fisheries for a systematic account. As described by Johal et al. [138], the morphometric characteristics of Tor putitora were classified into various ranges controlled characters i.e.- vast (environmental), moderate (intermediate) and narrow (genetical). Similar references from India included Bhowmick et al. [139], Chondar [140-142], Khan et al. [143], Tripathy et al. [144] and Sarangi et al. [145] and many more from time to time. Chondar [140-142] reported on systematic account of morphometric and meristic characters in hybrids of Indian major carps like catla rohu and mrigal. Sinha \& Khan [146] reported about occurrence of three intra-specific populations of catla in Rihand Dam, Madhya Pradesh, based on distinct morphometry. Khan et al. [143] reported morpho meristic account of rohu, mrigal and their 
inter-generic hybrids. In Tor putitora, meristic characters were independent of body size and there was no change with increasing body length [2]. Pandey \& Nautiyal [147], evaluated some meristic and morphometric characters of taxonomic significance in differentiating S. richardsonii (Gray) and S. plogiostomus (Heckle) to reveal fin length as characters of diagnostic significance, whereas Johal et al. [148] informed about morphometric and meristic characters of age and growth of golden mahseer Tor putitora from Himachal Pradesh but Ujjania et al. [149] reported morphometric and meristic characters of Tor tor from Udaipur. Goswami \& Dasgupta [150] studied morphometric and meristic characters of Nandus nandus (Gangetic leaf fish), as it was reported to be very much essential to record such characters of different species to solve race problem. They reported that, there was a proportional positive increase of morphometric characters with increasing in length.

Darshan et al. [151] identified Mystus ngasep in Manipur employing morphometry analysis. Tripathy et al. [152] reported morphometric analysis supported by generation mean analysis in various generations of catla and rohu, including their $\mathrm{F}_{1}$ hybrids and backcross populations following Balon [33] to study some of their hereditary trends. Brraich \& Akhter [153] investigated the morphometry and meristic accounts of Crossocheilus latius latius, whereas Brraich \& Akhter [154] reported morphometric characters and meristic counts of Garra gotyla gotyla (Gray). Morphometric characters and meristic count of Garra gotyla gotyla (Gray) were reported by Brraich \& Akhter [154] from Ranjit Sagar Wetland. Chakravorty et al. [28], morphometric variations and advancements indicated adaptive capability of Mystus spp. over varied geographical, climatic and nutritive factors. Mohan \& Sherly [155] reported the utility of morphometric and meristic analysis to separate species, populations, and races and the identification of species as well as the determination of sexual dimorphism in a goby fish, Oxyurichthys tentacularis. Dwivedi [156] determined morphometric variations in Indian major carps like rohu, mrigal, and catla from Ganga to detect hybrids and described it as a cost-effective method. Kaur et al. [62] studied morphometric characters in Labeo rohita (Hamilton-Buchanan), studying eighteen characters in percentage of total length, of which thirteen were reported to be genetically controlled, three were intermediate, and two were environmentally controlled, and observed a positive correlation between total length and external body parts. Priyanka et al. [157] reported that all species of the family Bagridae showed considerable variations in their morphometric and meristic characters, stating the role of such studies in species identification and measuring discreteness and relationships among various taxonomic categories.

\section{Conclusion}

Most of the phenotypic characters with significance for economic traits in fishes are measurable or quantitative. Those exhibit individual variations within a population. Their magnitudes depend on a large number of factors, like the number of genes and various environmental parameters. Morphometry enables us to know the growth and development of organisms. It also enables us to know the systematic variations and structures of population characteristics. Traditional methods have been updated from time to time with advanced technologies. Such advancements are like image analysis, principal component analysis, truss network analysis, and multivariate analysis to get more accurate information for upgrading knowledge and information. So, it is obvious that morphometry is significant for genetics, evolution, systematics, and taxonomy of fishes as well as applied aspects like stock management and identification. It has changed the face of fishery management and research with its appropriate application to identify and classify species, races, and stocks.

\section{Declarations}

\subsection{Data Availability Statement}

Data sharing is not applicable to this article.

\subsection{Funding}

The author received no financial support for the research, authorship, and/or publication of this article.

\subsection{Institutional Review Board Statement}

Not applicable.

\subsection{Informed Consent Statement}

Not applicable.

\subsection{Declaration of Competing Interest}

The author declare that there is no conflict of interests regarding the publication of this manuscript. In addition, the ethical issues, including plagiarism, informed consent, misconduct, data fabrication and/or falsification, double publication and/or submission, and redundancies have been completely observed by the author. 


\section{References}

[1] Nayman (1965). Growth and Ecology of fish population. Journal of Animal Ecology, 20, 201-219.

[2] Talwar, P. K., \& Jhingran, A. G. (1992). Inland fishes of India. Records of Indian Journal, 3, 19-24.

[3] Swain, D. P., Riddell, B. E., \& Murray, C. B. (1991). Morphological differences between hatchery and wild populations of coho salmon (Oncorhynchus kisutch): environmental versus genetic origin. Canadian Journal of Fisheries and Aquatic Sciences, 48(9), 1783-1791. doi:10.1139/f91-210.

[4] Bronte, C. R., Fleischer, G. W., Maistrenko, S. G., \& Pronin, N. M. (1999). Stock structure of Lake Baikal omul as determined by whole-body morphology. Journal of Fish Biology, 54(4), 787-798. doi:10.1111/j.1095-8649.1999.tb02033.x.

[5] Allendorf, F., Ryman, N., and Utter, F. 1987. Genetics and fishery management: Past, present, and future. - In: Ryman, N. and Utter, F. (eds.), Population Genetics and Fishery Management. pp. 1-19. Washington Sea Grant Publications/ University of Washington Press, Seattle, and London. Reprinted 2009 by The Blackburn Press, Caldwell, NJ.

[6] Wimberger, P. H. (1992). Plasticity of fish body shape. The effects of diet, development, family and age in two species of Geophagus (Pisces: Cichlidae). Biological Journal of the Linnean Society, 45(3), 197-218. doi:10.1111/j.10958312.1992.tb00640.x.

[7] Clarke, G. M. (1993). The genetic basis of developmental stability. I. Relationships between stability, heterozygosity and genomic coadaptation. In Genetica (Vol. 89, Issues 1-3). Genetica. doi:10.1007/BF02424502.

[8] Avsar, D. (1994). Diel diet and feeding behaviour of Scaldfish (Arnoglossus laterna VALBAUM, 1792) in the Bay on Mersin. Acta Adriatica, 34(1/2), 89-101.

[9] Kováč, V., Copp, G. H., \& Francis, M. P. (1999). Morphometry of the stone loach, Barbatula barbatula: Do mensural characters reflect the species' life history thresholds? Environmental Biology of Fishes, 56(1-2), 105-115. doi:10.1023/a:1007570716690.

[10] Cadrin, S. X. (2000). Advances in morphometric identification of fishery stocks. Reviews in Fish Biology and Fisheries, 10(1), 91-112. doi:10.1023/A:1008939104413.

[11] Cadrin, S. X., \& Friedland, K. D. (1999). The utility of image processing techniques for morphometric analysis and stock identification. Fisheries Research, 43(1-3), 129-139. doi:10.1016/S0165-7836(99)00070-3.

[12] Turan, C. (2004). Stock identification of Mediterranean horse mackerel (Trachurus mediterraneus) using morphometric and meristic characters. ICES Journal of Marine Science, 61(5), 774-781. doi:10.1016/j.icesjms.2004.05.001.

[13] Jaiswar, A. K., Parida, P. K., Chakraborty, S. K., \& Palaniswamy, R. (2004). Morphometry and length-weight relationship of obtuse barracuda Sphyraena obtusata (Cuvier) (TeleostorruVActinopterygii/Sphyraenidae) from Bombay waters, west coast of India. Indian Journal of Marine Sciences, 33(3), 307-309.

[14] Murta, A. G. (2000). Morphological variation of horse mackerel (Trachurus trachurus) in the Iberian and North African Atlantic: Implications for stock identification. ICES Journal of Marine Science, 57(4), 1240-1248. doi:10.1006/jmsc.2000.0810

[15] Pinheiro, A., Teixeira, C. M., Rego, A. L., Marques, J. F., \& Cabral, H. N. (2005). Genetic and morphological variation of Solea lascaris (Risso, 1810) along the Portuguese coast. Fisheries Research, 73(1-2), 67-78. doi:10.1016/j.fishres.2005.01.004.

[16] Schreck, C. B., \& Moyle, P. B. (1990). Methods for fish biology. American fisheries society. Bethesdu. Maryland. USA, 684.

[17] Ryu, D. K., Im, J. H., Kim, D. S., \& Nam, Y. K. (2001). Effect of starvation on morphometric changes in Rhynchocypris oxycephalus (Sauvage and Dabry). Journal of Applied Ichthyology, 17(6), 277-281. doi:10.1046/j.1439-0426.2001.00298.x

[18] Park, I. S., Lim, J. H., \& Hur, J. W. (2004). Morphometric characteristics of catfish (Siluridae) in Korea. Korean Journal of Ichthyology, 16, 223-228.

[19] Park, I. S., Woo, S. R., Song, Y. C., \& Cho, S. H. (2007). Effects of starvation on morphometric characteristics of olive flounder, Paralichthys olivaceus. Ichthyological Research, 54(3), 297-302. doi:10.1007/s10228-007-0404-4.

[20] Turan, C., Yalçin, Ş., Turan, F., Okur, E., \& Akyurt, I. (2005). Morphometric comparisons of African catfish, Clarias gariepinus, populations in Turkey. Folia Zoologica, 54(1-2), 165-172.

[21] Smith, P. J., \& Jamieson, A. (1986). Stock discreteness in herrings: A conceptual revolution. Fisheries Research, 4(3-4), 223234. doi:10.1016/0165-7836(86)90004-4.

[22] Randall, J. E., \& Pyle, R. L. (2008). Synodus orientalis, a new lizardfish (Aulopiformes: Synodontidae) from Taiwan and Japan, with correction of the Asian records of S. Lobeli. Zoological Studies, 47(5), 657-662.

[23] Hossain, M. A. R., Nahiduzzaman, M., Saha, D., Habiba Khanam, M. U., \& Alam, M. S. (2010). Landmark-based morphometric and meristic variations of the endangered carp, kalibaus Labeo calbasu, from stocks of two isolated rivers, the Jamuna and Halda, and a hatchery. Zoological Studies, 49(4), 556-563. 
[24] Sajina, A. M., Chakraborty, S. K., Jaiswar, A. K., Pazhayamadam, D. G., \& Sudheesan, D. (2011). Stock Structure Analysis of Indian Mackerel, Rastrelliger kanagurta (Cuvier, 1816) along the Indian Coast. Asian Fisheries Science, 24(3), 331-342. doi:10.33997/j.afs.2011.24.3.006.

[25] Mir, J. I., Sarkar, U. K., Dwivedi, A. K., Gusain, O. P., \& Jena, J. K. (2013). Stock structure analysis of Labeo rohita (Hamilton, 1822) across the Ganga basin (India) using a truss network system. Journal of Applied Ichthyology, 29(5), 1097-1103. doi:10.1111/jai.12141.

[26] Anumudu CI, M. T. (2015). Advanced Techniques for Morphometric Analysis in Fish. Journal of Aquaculture Research \& Development, 06(08), 354-359. doi:10.4172/2155-9546.1000354.

[27] Chaklader, R., Siddik, M. A. B., Hanif, A., Nahar, A., Mahmud, S., \& Piria, M. (2016). Morphometric and meristic variation of endangered pabda catfish, ompok pabda (Hamilton-buchanan, 1822) from southern coastal waters of Bangladesh. Pakistan Journal of Zoology, 48(3), 681-687.

[28] Chakravorty, K. (2016). Study of the Morphometry and Meristic Analyses of Three Mystus species from the Chandubi Beel, Kamrup District, Assam. International Journal of Life-Sciences Scientific Research, 2(4), $478-487$. doi:10.21276/ijlssr.2016.2.4.26.

[29] Begum, M., Al-Mamun, A., Islam, M., \& Alam, M. (1970). Morphometric characters and their relationship in estuarine catfish. Journal of the Bangladesh Agricultural University, 6(2), 349-353. doi:10.3329/jbau.v6i2.4833.

[30] Mekkawy, I. A. A., \& Mohammad, A. S. (2011). Morphometries and meristics of the three epinepheline species: Cephalopholis argus (Bloch and Schneider, 1801), Cephalopholis miniata (Forsskal, 1775) and Variola louti (Forsskal, 1775) from the Red Sea, Egypt. Journal of Biological Sciences, 11(1), 10-21. doi:10.3923/jbs.2011.10.21.

[31] Satyanarayana, M., \& Ratnakumari, C. H. V. (2018). Morphometric, meristic and comparative studies of Mystus three species (family-Bagridae) from two different habitats of Andhra Pradesh, India. Indian Journal of Biology, 5(1), 44-52.

[32] Batubara, A. S., Muchlisin, Z. A., Efizon, D., Elvyra, R., Fadli, N., \& Irham, M. (2018). Morphometric variations of the Genus Barbonymus (Pisces, Cyprinidae) harvested from Aceh Waters, Indonesia. In Archives of Polish Fisheries (Vol. 26, Issue 4, pp. 231-237). doi:10.2478/aopf-2018-0026.

[33] Elliott, N. G., Haskard, K., \& Koslow, J. A. (1995). Morphometric analysis of orange roughy (Hoplostethus atlanticus) off the continental slope of southern Australia. Journal of Fish Biology, 46(2), 202-220. doi:10.1111/j.1095-8649.1995.tb05962.x.

[34] Balon, E. K. (1995). Origin and domestication of the wild carp, Cyprinus carpio: from Roman gourmets to the swimming flowers. Aquaculture, 129(1-4), 3-48. doi:10.1016/0044-8486(94)00227-F.

[35] Uiblein, F. (1995). Morphological variability between populations of Neobythites stefanovi (Pisces:Ophidiidae) from the deep Red Sea and the Gulf of Aden. Marine Ecology Progress Series, 124, 23-29. doi:10.3354/meps124023.

[36] Hurlbut, T., \& Clay, D. (1998). Morphometric and meristic differences between shallow- and deep-water populations of white hake (Urophycis tenuis) in the southern Gulf of St. Lawrence. Canadian Journal of Fisheries and Aquatic Sciences, 55(10), 2274-2282. doi:10.1139/f98-110.

[37] Devi, N. T., Khumar, F., \& Siddiqui, M. S. (1991). Observations on the morphometric characters of the catfish Rita rita (Ham.) of the river Yamuna. Journal of Inland Fisheries Society India, 23, 52-58.

[38] Kohinoor, A. H. M., Saha, N. C., Akhteruzzaman, M., Shah, M. C., \& Mahata, S. C. (1995). Morphometric characters and their relationship in red tilapia (mutant Oreochromis mossumbicus X Oreochromis niloticus. Bangladesh Journal of Fisheries, 15-18, $19-24$.

[39] Narejo, N. T., Jafri, S. I. H., \& Shaikh, S. A. (2000). Studies on the age and growth of Palri, Gudusia chapra (Clupeidae: Teleostei) from the Keenjhar Lake (District: Thatta) Sindh, Pakistan. Pakistan Journal of Zoology, 32(4), 307-312.

[40] Carpenter, K. E., Sommer, H. J., \& Marcus, L. F. (1996). Converting Truss Interlandmark Distances to Cartesian Coordinates. Advances in Morphometrics, 284, 103-111. doi:10.1007/978-1-4757-9083-2_9.

[41] Silva, A. (2003). Morphometric variation among sardine (Sardina pilchardus) populations from the northeastern Atlantic and the western Mediterranean. ICES Journal of Marine Science, 60(6), 1352-60. doi:10.1016/S1054-3139(03)00141-3.

[42] O’Reilly, K. M., \& Horn, M. H. (2004). Phenotypic variation among populations of Atherinops affinis (Atherinopsidae) with insights from a geometric morphometric analysis. Journal of Fish Biology, 64(4), 1117-1135. doi:10.1111/j.10958649.2004.00379.x.

[43] Rohlf, F. J. (1998). On Applications of Geometric Morphometrics to Studies of Ontogeny and Phylogeny. Systematic Biology, 47(1), 147-158. doi:10.1080/106351598261094.

[44] Montiero, L. R. (2000). Why morphometrics is special: The problem with the using partial warps as characters for phylogenetic inference. Systematic Biology, 49(4), 796-800. doi:10.1080/106351500750049833. 
[45] Bookstein, F. L. (2003). Creases as morphometric characters. In M. N. \& F. P. L (Eds.), Morphology, Shape and Phylogeny. Taylor \& Francis. doi:10.1201/9780203165171.

[46] Klingenberg, C. P., \& Gidaszewski, N. A. (2010). Testing and quantifying phylogenetic signals and homoplasy in morphometric data. Systematic Biology, 59(3), 245-261. doi:10.1093/sysbio/syp106.

[47] Naeem, M. \& Salam, A. (2005). Morphometric Study of Fresh Water Bighead Carp Aristichthys nobilis from Pakistan in Relation to Body Size. Pakistan Journal of Biological Sciences, 8(5), 759-762. doi:10.3923/pjbs.2005.759.762.

[48] Sarder, M. R. I., \& Simonsen, V. (2006). Final report on the study and workshop on causes for and consequences of reduced growth in Indian major carps (p. 62).

[49] Eklöv, P., \& Svanbäck, R. (2006). Predation risk influences adaptive morphological variation in fish populations. In American Naturalist (Vol. 167, Issue 3). American Nationals. doi:10.1086/499544.

[50] King, M. (2008). Review of "Fisheries Biologya, Assessment and Managenement." Review of Fish Biology and Fisheries, 8 , $451-452$.

[51] Cheng, Q. Q., Lu, D. R., \& Ma, L. (2005). Morphological differences between close populations discernible by multivariate analysis: A case study of genus Coilia (Teleostei: Clupeiforms). Aquatic Living Resources, 18(2), $187-192$. doi:10.1051/alr:2005020.

[52] Buj, I., Podnar, M., Mrakovčić, M., Ćaleta, M., Mustafić, P., Zanella, D., \& Marččić, Z. (2008). Morphological and genetic diversity of Sabanejewia balcanica in Croatia. Folia Zoologica, 57(1-2), 100-110.

[53] Torres R., G. A., González P., S., \& Peña S., E. (2010). Anatomical, histological and ultraestructural description of the gills and liver of the tilapia (Oreochromis niloticus). Int. j. Morphol, 28(3), 703-712. doi:10.4067/S0717-95022010000300008.

[54] Cadrin, S. X., \& Silva, V. M. (2005). Morphometric variation of yellowtail flounder. ICES Journal of Marine Science, 62(4), 683-694. doi:10.1016/j.icesjms.2005.02.006.

[55] Chaklader, R., Bakar Siddik, M. A., \& Nahar, A. (2015). Taxonomic diversity of paradise threadfin polynemus paradiseus (Linnaeus, 1758) inhabiting southern coastal rivers in Bangladesh. Sains Malaysiana, 44(9), 1241-1248. doi:10.17576/jsm2015-4409-04.

[56] Siddik, M. A. B., Hanif, M. A., Chaklader, M. R., Nahar, A., \& Mahmud, S. (2015). Fishery biology of gangetic whiting Sillaginopsis panijus (Hamilton, 1822) endemic to Ganges delta, Bangladesh. Egyptian Journal of Aquatic Research, 41(4), 307313. doi:10.1016/j.ejar.2015.11.001.

[57] Siddik, M. (2016). Stock Identification of Critically Endangered Olive Barb, Puntius sarana (Hamilton, 1822) with Emphasis on Management Implications. Journal of Aquaculture Research \& Development, 07(02). doi:10.4172/2155-9546.1000411.

[58] Poulet, N., Berrebi, P., Crivelli, A. J., Lek, S., \& Argillier, C. (2004). Genetic and morphometric variations in the pikeperch (Sander lucioperca L.) of a fragmen0ted delta. Archiv Fur Hydrobiologie, 159(4), 531-554. doi:10.1127/0003-9136/2004/01590531 .

[59] Turan, C., Oral, M., Öztürk, B., \& Düzgüneş, E. (2006). Morphometric and meristic variation between stocks of Bluefish (Pomatomus saltatrix) in the Black, Marmara, Aegean and northeastern Mediterranean Seas. In Fisheries Research (Vol. 79, Issues 1-2). Fisheries Research. doi:10.1016/j.fishres.2006.01.015.

[60] Akbarzadeh, A., Farahmand, H., Shabani, A. A., Karami, M., Kaboli, M., Abbasi, K., \& Rafiee, G. R. (2009). Morphological variation of the pikeperch Sander lucioperca (L.) in the southern Caspian Sea, using a truss system. Journal of Applied Ichthyology, 25(5), 576-582. doi:10.1111/j.1439-0426.2009.01308.x.

[61] Adams, D. C., Rohlf, F. J., \& Slice, D. E. (2013). A field comes of age: Geometric morphometrics in the 21st century. Hystrix, 24(1), 7-14. doi:10.4404/hystrix-24.1-6283.

[62] Kaur, V., Ana, Y., \& Heer, B. K. (2019). Morphometric analysis of fish, Labeo rohita (Hamilton). International Journal of Fisheries and Aquatic Studies, 7(3), 299-306.

[63] Winans, G. A. (1984). Multivariate morphological variability in pacific salmons: Technical demonstration. Canadian Journal of Fisheries and Aquatic Sciences, 41, 1150-1159.

[64] Wainwright, P. C. (1988). Morphology and ecology: functional basis of feeding constraints in Caribbean labrid fishes. Ecology, 69(3), 635-645. doi:10.2307/1941012.

[65] Wikramanayake, E. D. (1990). Ecomorphology and biogeography of a tropical stream fish assemblage: evolution of assemblage structure. Ecology, 71(5), 1756-1764. doi:10.2307/1937583.

[66] Rohlf, F., \& Marcus, L. (1993). A revolution in morphometrics. Trends in Ecology \& Evolution, 8(4), 129-132.

[67] Rohlf, F. J. (1993). In: Marcus, L. F., Bello, E. \& Garcia-Valdecasa, A. G. (Eds). Contributions to morphometrics. Madrid: Museo Nacional de Ciencias Naturales; 131-59. 
[68] Rohlf, F. J. (1990). Morphometrics. Annual Review of Ecology and Systematics, 21, 299-316.

[69] Bonhomme, V., Picq, S., Gaucherel, C., \& Claude, J. (2014). Momocs: Outline analysis using R. Journal of Statistical Software, 56(13), 1-24. doi:10.18637/jss.v056.i13.

[70] Fitzgerald, D. G., Nanson, J. W., Todd, T. N., \& Davis, B. M. (2002). Application of truss analysis for the quantification of changes in fish condition. Journal of Aquatic Ecosystem Stress and Recovery, 9(2), 115-125. doi:10.1023/A:1014438510692.

[71] Chen, Y., Bart, H. L., \& Teng, F. (2005). A content-based image retrieval system for fish taxonomy. Proceedings of the 7th ACM SIGMM International Workshop on Multimedia Information Retrieval - MIR ’05. doi:10.1145/1101826.1101864.

[72] Caillon, F., Bonhomme, V., Möllmann, C., \& Frelat, R. (2018). A morphometric dive into fish diversity. Ecosphere, 9(5). doi:10.1002/ecs2.2220.

[73] Lele, S., \& Bookstein, F. L. (1999). Morphometric Tools for Landmark Data: Geometry and Biology. In Journal of the American Statistical Association (Vol. 94, Issue 445). Cambridge Univ. Press. doi:10.2307/2669711.

[74] Cavalcanti, M. J., Monteiro, L. R., \& Lopes, P. R. D. (1999). Landmark-based morphometric analysis in selected species of serranid fishes (Perciformes: Teleostei). Zoological Studies, 38(3), 287-294.

[75] Parsons, K. J., Robinson, B. W., \& Hrbek, T. (2003). Getting into shape: An empirical comparison of traditional truss-based morphometric methods with a newer geometric method applied to New World cichlids. Environmental Biology of Fishes, 67(4), 417-431. doi:10.1023/A:1025895317253.

[76] Toscano, B. J., Pulcini, D., Hayden, B., Russo, T., Kelly-Quinn, M., \& Mariani, S. (2010). An ecomorphological framework for the coexistence of two cyprinid fish and their hybrids in a novel environment. Biological Journal of the Linnean Society, 99(4), 768-783. doi:10.1111/j.1095-8312.2010.01383.x.

[77] Echem, R. T. (2016). Geometric Morphometric Analysis of Shape Variation of Sardinella lemuru. International Journal of Advanced Research in Biological Sciences (IJARBS), 3(9), 91-97. doi:10.22192/ijarbs.2016.03.09.013.

[78] Strauss, R. E., \& Bookstein, F. L. (1982). The Truss: Body Form Reconstructions in Morphometrics. Systematic Biology, 31(2), 113-135. doi:10.1093/sysbio/31.2.113.

[79] Reyment, R. A., Bookstein, F. L., Chernoff, B., Elder, R. L., Humphries, J. M., Smith, G. R., \& Strauss, R. E. (1986). Morphometrics in Evolutionary Biology. Biometrics, 42(4), 1002. doi:10.2307/2530720.

[80] Humphries, J. M., Bookstein, F. L., Chernoff, B., Smith, G. R., Elder, R. L., \& Poss, S. G. (1981). Multivariate Discrimination by Shape in Relation to Size. Systematic Zoology, 30(3), 291. doi:10.2307/2413251.

[81] Currens, K. P., Sharpe, C. S., Hjort, R., Schreck, C. B., \& Li, H. W. (1989). Effects of Different Feeding Regimes on the Morphometrics of Chinook Salmon (Oncorhynchus tshawytscha) and Rainbow Trout (O. mykiss). Copeia, 1989(3), 689. doi: $10.2307 / 1445496$.

[82] Corti, M., Thorpe, R. S., Sola, L., Sbordoni, V., \& Cataudella, S. (1988). Multivariate morphometrics in aquaculture: A case study of six stocks of the common carp (Cyprinus carpio) from Italy. Canadian Journal of Fisheries and Aquatic Sciences, 45(9), 1548-1554. doi:10.1139/f88-183.

[83] Roby, D., Lambert, J. D., \& Sévigny, J. M. (1991). Morphometric and Electrophoretic Approaches to Discrimination of Capelin ( Mallotus villosus ) Populations in the Estuary and Gulf of St. Lawrence . Canadian Journal of Fisheries and Aquatic Sciences, 48(11), 2040-2050. doi:10.1139/f91-243.

[84] Baumgartner, J. V. (1995). Phenotypic, genetic, and environmental integration of morphology in a stream population of the threespine stickleback, Gasterosteus aculeatus. Canadian Journal of Fisheries and Aquatic Sciences, 52(6), $1307-1317$. doi:10.1139/f95-127.

[85] Hauser, L., Carvalho, G. R., \& Pitcher, T. J. (1995). Morphological and genetic differentiation of the African clupeid Limnothrissa miodon 34 years after its introduction to Lake Kivu. Journal of Fish Biology, 47(Suppl. A), $127-144$. doi:10.1111/j.1095-8649.1995.tb06049.x.

[86] Bembo, D. G., Carvalho, G. R., Cingolani, N., \& Pitcher, T. J. (1996). Electrophoretic analysis of stock structure in Northern Mediterranean anchovies, Engraulis encrasicolus. ICES Journal of Marine Science, 53(1), 115-128. doi:10.1006/jmsc.1996.0011

[87] Turan, C. (1999). A note on the examination of morphometric differentiation among fish populations: The Truss System. Turkish Journal of Zoology, 23(3), 259-263.

[88] Turan, C., Ergüden, D., Gürlek, M., Başusta, N., \& Turan, F. (2004). Morphometric structuring of the anchovy (Engraulis encrasicolus L.) in the black, Aegean and Northeastern Mediterranean seas. Turkish Journal of Veterinary and Animal Sciences, $28(5), 865-871$.

[89] Bronte, C. R., \& Moore, S. A. (2007). Morphological Variation of Siscowet Lake Trout in Lake Superior. Transactions of the American Fisheries Society, 136(2), 509-517. doi:10.1577/t06-098.1. 
[90] Shao, Y., Wang, J., Qiao, Y., He, Y., \& Cao, W. (2007). Morphological variability between wild populations and inbred stocks of a Chinese minnow, Gobiocypris rarus. Zoological Science, 24(11), 1094-1102. doi:10.2108/zsj.24.1094.

[91] Dwivedi, A. K., \& Dubey, V. K. (2013). Advancements in morphometric differentiation: A review on stock identification among fish populations. Reviews in Fish Biology and Fisheries, 23(1), 23-39. doi:10.1007/s11160-012-9279-1.

[92] Park, I.-S., Gil, H. W., Oh, J. S., Choi, H. J., \& Kim, C. H. (2015). Comparative Analysis of Morphometric Characteristics of Scorpaenidae and Gobioninae. Development \& Reproduction, 19(2), 85-96. doi:10.12717/dr.2015.19.2.085.

[93] Suryaningsih, S., Bhagawati, D., Sukmaningrum, S., Sugiharto, \& Ayu Ratna Puspitasari, I. (2020). The Morphometrical Character of Silver Barb Fish Barbonymus gonionotus (Bleeker, 1849). IOP Conference Series: Earth and Environmental Science, 593, 012027. doi:10.1088/1755-1315/593/1/012027.

[94] Legendre, P., \& Legendre, L. (2012). Numerical ecology. Developments in Environmental Modelling. Elsevier, Amsterdam, Netherlands.

[95] Robertson, M. P., Caithness, N., \& Villet, M. H. (2001). A PCA-based modelling technique for predicting environmental suitability for organisms from presence records. Diversity and Distributions, 7(1-2), 15-27. doi:10.1046/j.14724642.2001.00094.x.

[96] Kusznierz, J., Kotusz, J., Popiołek, M., \& Witkowski, A. (2008). Remarks on the morphological variability of the Arctic charr, Salvelinus alpinus (L.) from Spitsbergen. Polish Polar Research, 29(3), 227-236.

[97] Bektas, Y., \& Belduz, A. O. (2009). Morphological variation among atlantic horse mackerel, Trachurus trachurus populations from Turkish coastal waters. Journal of Animal and Veterinary Advances, 8(3), 511-517.

[98] Specziár, A., Bercsényi, M., \& Müller, T. (2009). Morphological characteristics of hybrid pikeperch (Sander lucioperca $\varnothing \times$ Sander volgensis 3 ) (Osteichthyes, Percidae). Acta Zoologica Academiae Scientiarum Hungaricae, 55(1), 39-54.

[99] Yakubu, A., \& Okunsebor, S. A. (2011). Morphometric Differentiation of Two Nigerian Fish Species (Oreochromis niloticus and Lates niloticus) Using Principal Components and Discriminant Analysis. International Journal of Morphology, 29(4), 14291434. doi: $10.4067 / \mathrm{s} 0717-95022011000400060$.

[100] Cronin-Fine, L., Stockwell, J. D., Whitener, Z. T., Labbe, E. M., Willis, T. V., \& Wilson, K. A. (2013). Application of Morphometric Analysis to Identify Alewife Stock Structure in the Gulf of Maine. Marine and Coastal Fisheries, 5(1), 11-20. doi:10.1080/19425120.2012.741558.

[101] Hard, J. J., Berejikian, B. A., Tezak, E. P., Schroder, S. L., Knudsen, C. M., \& Parker, L. T. (2000). Evidence for morphometric differentiation of wild and captively reared adult coho salmon: A geometric analysis. Environmental Biology of Fishes, 58(1), 61-73. doi:10.1023/A:1007646332666.

[102] Gonzalez-Martinez, A., Lopez, M., Molero, H. M., Rodriguez, J., González, M., Barba, C., \& García, A. (2020). Morphometric and meristic characterization of native chame fish (Dormitator latifrons) in Ecuador using multivariate analysis. Animals, 10(10), 1-19. doi:10.3390/ani10101805.

[103] Vatandoust, S., Mousavi-Sabet, H., Razeghi-Mansour, M., AnvariFar, H., \& Heidari, A. (2015). Morphometric variation of the endangered Caspian lamprey, Caspiomyzon wagneri (Pisces: Petromyzontidae), from migrating stocks of two rivers along the southern Caspian Sea. Zoological Studies, 54(AUGUST), 56-58. doi:10.1186/s40555-015-0133-8.

[104] Costa, C., Loy, A., Cataudella, S., Davis, D., \& Scardi, M. (2006). Extracting fish size using dual underwater cameras. Aquacultural Engineering, 35(3), 218-227. doi:10.1016/j.aquaeng.2006.02.003.

[105] Shubinkova, N. G. (1980). Morphometric characteristics and and variability of silver carps Hypothalmichthys moltrix (Val.) in the ponds of the Akkurgan fish farm. Vopr. Ikhtiology, 20(1), 149-156.

[106] Ihssen, P. E., Brooke, H. E., Casselman, J. M., Meglade, J. M., Pyne, N. R., \& Utter, F. M. (1981). Stock identification: materials and methods. Canadian Journal of Fisheries and Aquatic Sciences, 30, 1838-1855.

[107] Riddell, B. E., \& Leggett, W. C. (1981). Evidence of an Adaptive Basis for Geographic Variation in Body Morphology and Time of Downstream Migration of Juvenile Atlantic Salmon (Salmo salar) . Canadian Journal of Fisheries and Aquatic Sciences, 38(3), 308 - 320. doi:10.1139/f81-042.

[108] Strauss, R. E., \& Fuiman, L. A. (1985). Quantitative comparisons of body form and allometry in larval and adult Pacific sculpins (Teleostei: Cottidae). Canadian Journal of Zoology, 63(7), 1582-1589. doi:10.1139/z85-234.

[109] Swain, D. P., \& Holtby, L. B. (1989). Differences in morphology and behavior between juvenile coho salmon (Oncorhynchus kisutch) rearing in a lake and in its tributary stream. Canadian Journal of Fisheries and Aquatic Sciences, 46(8), 1406-1414. doi:10.1139/f89-180.

[110] Beeman, J. W., Rondorf, D. W., \& Tilson, M. E. (1994). Assessing smoltification of juvenile spring chinook salmon (Oncorhynchus tshawytscha) using changes in body morphology. Canadian Journal of Fisheries and Aquatic Sciences, 51(4), 836-844. doi:10.1139/f94-082. 
[111] Beeman, J. W., Rondorf, D. W., Tilson, M. E., \& Venditti, D. A. (1995). A Nonlethal Measure of Smolt Status of Juvenile Steelhead Based on Body Morphology. Transactions of the American Fisheries Society, 124(5), 764-769. doi:10.1577/15488659(1995)124<0764:anmoss>2.3.co;2.

[112] Leary, R. F., Allendorf, F. W., \& Knudsen, K. L. (1985). Inheritance of meristic variation and the evolution of developmental stability in rainbow trout. Evolution, 39(2), 308-314. doi:10.1111/j.1558-5646.1985.tb05668.x.

[113] Spanakis, E., Tsimenides, N., \& Zouros, E. (1989). Genetic differences between populations of sardine, Sardina pilchardus, and anchovy, Engraulis encrasicolus, in the Aegean and Ionian seas. Journal of Fish Biology, 35(3), 417-437. doi:10.1111/j.1095-8649.1989.tb02993.x.

[114] Reist, J. D., Vuorinen, J., \& Bodaly, R. A. (1992). Genetic and morphological identification of coregonid hybrid fishes from Arctic Canada. Polskie Archiwum Hydrobiologii, 39(3-4), 551-561.

[115] Carvalho, G. R., \& Hauser, L. (1994). Molecular genetics and the stock concept in fisheries. Reviews in Fish Biology and Fisheries, 4(3), 326-350. doi:10.1007/BF00042908.

[116] Baranyi, C., Gollmann, G., \& Bobin, M. (1997). Genetic and morphological variability in roach Rutilus rutilus, from Austria. Hydrobiologia, 350(1-3), 13-23. doi:10.1023/a:1003056311181.

[117] Rosenfield, J. A. (1998). Detection of natural hybridization between pink salmon (Oncorhynchus gorbuscha) and chinook salmon (Oncorhynchus tshawytscha) in the Laurentian Great Lakes using meristic, morphological, and color evidence. Copeia, 3(3), 706-714. doi:10.2307/1447801.

[118] Hockaday, S., Beddow, T. A., Stone, M., Hancock, P., \& Ross, L. G. (2000). Using truss networks to estimate the biomass of Oreochromis niloticus, and to investigate shape Characteristics. Journal of Fish Biology, 57(4), 981-1000. doi:10.1111/j.10958649.2000.tb02206.x.

[119] Katoh, M., \& Tokimura, M. (2001). Genetic and morphological identification of Sebastiscus tertius in the East China Sea (Scorpaeniformes: Scorpaenidae). Ichthyological Research, 48(3), 247-255. doi:10.1007/s10228-001-8142-5.

[120] Zafar, M., Nazir, A., . N. A., . S. M. H. M. N., \& . M. Z.-R. (2002). Studies on Meristic Counts and Morphometric Measurements of Mahseer (Tor putitora) from a Spawning Ground of Himalayan Foot-hill River Korang Islamabad, Pakistan. Pakistan Journal of Biological Sciences, 5(6), 733-735. doi:10.3923/pjbs.2002.733.735.

[121] Chakrabarty, P., \& Ng, H. H. (2005). The identity of catfishes identified as Mystus cavasius (Hamilton, 1822) (Teleostei: Bagridae), with a description of a new species from Myanmar. Zootaxa, 1093(1093), 1-24. doi:10.11646/zootaxa.1093.1.1.

[122] Ibáñez-Aguirre, A. L., Cabral-Solís, E., Gallardo-Cabello, M., \& Espino-Barr, E. (2006). Comparative morphometrics of two populations of Mugil curema (Pisces: Mugilidae) on the Atlantic and Mexican Pacific coasts. Scientia Marina, 70(1), $139-145$. doi:10.3989/scimar.2006.70n1139.

[123] Katselis George; Minos, George and Vidalis, Kosmas, G. H. (2006). Phenotypic affinities on fry of four mediterranean grey mullet species. Turkish Journal of Fisheries and Aquatic Sciences, 6, 49-55.

[124] Sakai, H., Iguchi, K., Yamazaki, Y., Sideleva, V. G., \& Goto, A. (2009). Morphological and mtDNA sequence studies on three crucian carps (Carassius: Cyprinidae) including a new stock from the Ob river system, Kazakhstan. Journal of Fish Biology, 74(8), 1756-1773. doi:10.1111/j.1095-8649.2009.02203.x.

[125] Flipos, E. (2014). Morphometric relations, diet composition and ontogenetic dietary shift of Labeobarbus intermedius (Ruppell, 1836) in Lake Tana gulf of Gorgora, Ethiopia. International Journal of Fisheries and Aquaculture, 6(11), 124-132. Available online: http://www.academicjournals.org/article/article1416303880_Flipos.pdf (accessed on April 2020).

[126] Makmur, S., Arfiati, D., Bintoro, G., \& Ekawati, A. W. (2014). Morphological, meristic characteristics and mtDNA analysis of Hampala Fish (Hampala macrolepidota Kuhl \& Van Hasselt 1823) from ranau lake, Indonesia. Journal of Biodiversity and Environmental Sciences, 447(2), 447-455.

[127] Solomon, S. G., Okomoda, V. T., \& Ogbenyikwu, A. I. (2015). Intraspecific morphological variation between cultured and wild Clarias gariepinus (Burchell) (Clariidae, Siluriformes). Archives of Polish Fisheries, 23(1), 53-61. doi:10.1515/aopf2015-0006.

[128] Jacquemin, S. J., \& Pyron, M. (2016). A century of morphological variation in Cyprinidae fishes. BMC Ecology, 16(1), 4866. doi:10.1186/s12898-016-0104-x.

[129] Siddik, M. A. B., Hanif, M. A., Chaklader, M. R., Nahar, A., \& Fotedar, R. (2016). A multivariate morphometric investigation to delineate stock structure of gangetic whiting, Sillaginopsis panijus (Teleostei: Sillaginidae). In SpringerPlus (Vol. 5, Issue 1). Springer Plus. doi:10.1186/s40064-016-2143-3.

[130] Tzeng, T. Der. (2004). Morphological variation between populations of spotted mackerel (Scomber australasicus) off Taiwan. Fisheries Research, 68(1-3), 45-55. doi:10.1016/j.fishres.2004.02.011. 
[131] Haddon, M., \& Willis, T. J. (1995). Morphometric and meristic comparison of orange roughy (Hoplostethus atlanticus: Trachichthyidae) from the Puysegur Bank and Lord Howe Rise, New Zealand, and its implications for stock structure. Marine Biology, 123(1), 19-27. doi:10.1007/BF00350319.

[132] Turan, C. (2000). Otolith shape and meristic analysis of herring (Clupea harengus) in the North-East Atlantic. Archive of Fishery and Marine Research, 48(3), 213-225.

[133] Pakkasmaa, S., \& Piironen, J. (2001). Morphological differentiation among local trout (Salmo trutta) populations. Biological Journal of the Linnean Society, 72(2), 231-239. doi:10.1006/bij1.2000.0488.

[134] Turan, C., Ergüden, D., Turan, F., \& Gürlek, M. (2004). Genetic and morphologic structure of Liza abu (Heckel, 1843) populations from the rivers Orontes, Euphrates and Tigris. Turkish Journal of Veterinary and Animal Sciences, 28(4), 729734.

[135] Gonźlez, M. A., Rodriguez, J. M., Angón, E., Martínez, A., Garcia, A., \& Peña, F. (2016). Characterization of morphological and meristic traits and their variations between two different populations (wild and cultured) of Cichlasoma festae, a species native to tropical Ecuadorian rivers. In Archives Animal Breeding, 59(4). Archives of Animal Breeding. doi:10.5194/aab-59435-2016.

[136] Caez, J., Gonzalez, A., González, M. A., Angón, E., Rodriguez, J. M., Peña, F., Barba, C., \& Garcia, A. (2019). Application of multifactorial discriminant analysis in the morphostructural differentiation of wild and cultured populations of Vieja Azul (Andinoacara rivulatus). Turkish Journal of Zoology, 43(5), 516-530. doi:10.3906/zoo-1903-31.

[137] Olopade, O. A., Dienye, H. E., Jimba, B., \& Bamidele, N. A. (2018). Observations on the morphometric and meristic characters of Guinean Tilapia, Coptodon guineensis (Günther, 1892) (Family: Cichlidae) from the Buguma Creek and the New Calabar River in Nigeria. Jordan Journal of Biological Sciences, 11(3), 247-255.

[138] Johal, M. S., Tandon, K. K., \& Sandhu, G. S. (1994). Mahseer in Lacustrine Waters, Gobindsagar Reservoir. In P. Nautiyal (Ed.), Mahseer the Game Fish, 67-85. Jagdamba, Prakashan Publisher.

[139] Bhowmick, R. M., Jana, R. K., Gupta, S. D., Kowtal, G. V., \& Rout, M. (1981). Studies on some aspects of biology and morphometry of the intergeneric hybrid, Catla catla Hamilton $\times$ Labeo rohita Hamilton produced by hypophysation. Aquaculture, 23(1-4), 367-371. doi:10.1016/0044-8486(81)90030-2.

[140] Chondar, S. L. (1985). Systematic account of carp hybrid Nadina II, Labeo rohita male x Catla catla female. Journal of Inland Fisheries Society of India, CIFRI, Kolkata, 17(1\&2), 66-70.

[141] Chondar, S. L. (1986 a). Systematic account of carp hybrids III, Catla catla male x Labeo rohita female. Journal of Inland Fisheries Society of India, CIFRI, Kolkata, 18(1), 29-33.

[142] Chondar, S. L. (1986 b). Systematic account of carp hybrids IV, Cirrihnus mrigala x Labeo rohita. Journal of Inland Fisheries Society of India, CIFRI, Kolkata, 18(2), 79-82.

[143] Khan, H. A., Reddy, P. V. G. K., \& Gupta, S. D. (1989). Studies on some aspects of biology and morphology of the intergeneric hybrid Cyprinus carpio var. Communis L. X Labeo rohita (Hamilton). Proc. Natl. Acad. Sci. India, 59, 155-162.

[144] Tripathy, S. K., Sarangi, N., \& Gaur, K. K. (2001). Morphometry of the Indian major Carps hybrids Catla catla (Ham.) x Labeo rohita (Ham. Journal of Agricultural and Scientific Research, 37(1\&2), 78-81.

[145] Sarangi, N., Tripathy, S. K., Mandal, A. B., \& Ahalawat, S. P. S. (2002). Studies on some genetical trends in backcross populations of Indian Major Carps viz.- Catla catla and Labeo rohita. Proceedings of Fifth Indian Fisheries Forum, Held in Central Institute of Freshwater Aquaculture.

[146] Sinha, V. R. P., \& Khan, H. A. (32676 B.C.E.). Genetic improvement of Indian major carps for aquaculture industry. In P. Das \& A. D. Jhingran (Eds.), Fish Genetics in India, 141-146. Today and Tomorrow Printers and Publishers.

[147] Pandey S K, N. P. (1997). Statistical evaluation of some meristic and morphometric characters of taxonomic significance in Schizothorax richardsonii (Gray) and Schizothorax plagiostomus (Heckel). Indian Journal of Fisheries, 44(1), 75-79.

[148] Johal, M. S., Negi, R. K., \& Negi, T. (2003). Age and growth of golden mahseer Tor putitora from Pong reservoir, Himachal Pradesh, India. Him J Env Zools, 17(2), 17-29.

[149] Ujjania, N. C., Kumar, G., Langar, R. K., \& Krishna, G. (2012). Biometric studies of mahseer (Tor Ham. 1822) from Bari Talab (Udaipur. India. International Journal of Inn. Bioscience, 2(3), 138-141.

[150] Goswami, S., \& Dasgupta, M. (2007). Analysis of the morphometric and meristic characters of the fish Nandus nandus Hamilton from the new alluvial zone of West Bengal. Records of the Zoological Survey of India. January-March, 1071(July 2003), 81-90.

[151] Darshan, A., Vishwanath, W., Mahanta, P. C., \& Barat, A. (2011). Mystus ngasep, a new catfish species (Teleostei: Bagridae) from the headwaters of Chindwin drainage in Manipur, India. Journal of Threatened Taxa, 3(11), $2177-2183$. doi:10.11609/jott.o2180.2177-83. 
[152] Tripathy, S. K., Gaur, K. K., \& Sarangi, N. (2013). Morphotypes vis-a-vis genetic parameters of Catla catla (Ham.) and Labeo rohita (Ham.) backcrosses. African Journal of Biotechnology, 12(36), 5503-5512. doi:10.4314/AJB.V12I36.

[153] Brraich, O. S., \& Akhter, S. (2015 a). Morphometric characters and meristic counts of a fish, Crossocheilus latius latius (Hamilton-Buchanan) from Ranjit Sagar Wetland, India. International Journal of Fisheries and Aquatic Studies, 2(5), 260-265.

[154] Brraich, O. S. \& Akhter, S. (2015 b). Morphometric characters and meristic counts of a fish, Garra gotyla gotyla (Gray) from Ranjit Sagar Wetland, situated in the Himalayan foothills, India. International Research Journal of Biological Sciences, 4(5), 66-72.

[155] Mohan, R., \& Williams, S. (2018). A Study of Morphometry and Meristic Counts of Oxyurichthys tentacularis , Gobiidae (Valenciennes , 1837 ) from Ashtamudi Lake- Kollam , Kerala. International Journal of Fisheries and Aquaculture Sciences, $8(1), 13-18$.

[156] Dwivedi, A. K. (2019). Detecting natural hybridization among Indian major carps through advance morphometric approach. BioRxiv. doi:10.1101/553941.

[157] Priyanka, C., Tewari, G., Datta, S. N., \& T, N. K. B. (2018). Morphometric and meristic variations in different fish species of family Bagridae from Harike wetland. Journal of Entomology and Zoology Studies, 8(4), 1788-1793. 